\title{
PERKULIAHAN DARING DI MASA PANDEMI COVID-19
}

\author{
Devi Clise Yuliana Putri \\ Program Studi Ekonomi Syariah Institut Agama Islam Negeri Ponorogo \\ E-mail : deviclise37@gmail.com
}

Website : https://jurnal.uin-antasari.ac.id/index.php/ptkpend/index

Received: 17 Oktober 2020; Accepted: 29 Desember 2020; Published: 1 Januari 2021

\begin{abstract}
The purpose of this study is to provide an overview of online lectures during the Covid-19 pandemic. With the use of content analysis methods. The analysis was carried out on various international, national articles and various similar sources related to online lectures during the Covid-19 pandemic. Online lectures using several applications in the form of: Zoom, Whatsapp, Google Classroom, E-Learning, Google Meet, and Youtube. When online lectures the problem is internet quota, the signal is difficult, some even don't have a smartphone or laptop.
\end{abstract}

Keywords: Activities; Online Lectures; Students; Covid-19 Pandemic

\section{Abstrak}

Tujuan penelitian ini adalah sebagai tinjauan umum terkait perkuliahan daring di masa pandemi Covid-19. Dengan penggunaan metode analisis isi. Analisis dilakukan pada berbagai artikel internasional, nasional dan berbagai sumber yang sejenis yang terkait perkuliahan daring di masa pandemi Covid-19. Perkuliahan daring dengan menggunakan beberapa aplikasi berupa : Zoom, Whatsapp, Google Classroom, E-Learning, Google Meet, dan Youtube. Saat perkuliahan online yang bermasalah adalah kuota internet, sinyalnya susah, bahkan ada yang tidak punya smartphone atau laptop.

Kata kunci: Aktivitas; Kuliah Online; Mahasiswa; Pandemi Covid-19

\section{PENDAHULUAN}

Hingga hari ini Indonesia masih dilanda pandemi Covid-19. Wabah virus corona adalah penyakit berupa virus yang menyerang pada sistem pernapasan. Penyakit karena infeksi virus ini disebut Covid-19. Virus Covid-19 pertama kali ditemukan di kota Wuhan, China pada tahun $2019 \quad$ (Ilmiyah,2020; Hui,et al..,2020). Virus ini memiliki karakteristik kecepatan penyebaran yang tinggi dan saat ini terkonfirmasi sudah ada kasus positif Covid-19 di 220 negara di seluruh dunia termasuk Indonesia.

Hingga saat ini 28 November 2020, Indonesia telah melaporkan 527.999 kasus positif, 441.983 pasien sembuh, dan 16.646 dilaporkan meninggal dunia
(Gugus Tugas Percepatan Penanganan Covid-19 Indonesia,2020). Untuk meminimalisir lonjakan pasien positif virus Covid-19, pemerintah membuat beberapa kebijakan yakni larangan untuk berkerumun, pembatasan sosial (social distancing), menjaga jarak (physical distancing), menggunakan masker dan selalu mencuci tangan. Kementerian Pendidikan dan Kebudayaan telah mengeluarkan Surat Edaran pada 17 Maret 2020 yang berisi anjuran tentang semua proses pembelajaran dan bekerja dilakukan secara daring dari rumah dalam rangka untuk pencegahan penyebaran Covid-19 (Sari . 2020) 
Saat ini program belajar secara daring merupakan cara yang bisa digunakan oleh setiap perguruan tinggi maupun lembaga pendidikan lainnya untuk melaksanakan proses perkuliahan dan proses belajar mengajar. Perkuliahan secara daring dilakukan oleh perguruan tinggi agar kegiatan perkuliahan dapat tetap dilaksanakan secara efektif dan efisien meskipun tidak dilakukan secara bertatap muka. Tujuan dari kajian ini adalah untuk memberikan tinjauan umum terkait perkuliahan daring di masa pandemi Covid-19 di Indonesia. Ini penting guna untuk mengetahui dampak perkuliahan daring terhadap mahasiswa di Indonesia.

\section{METODE PENELITIAN}

Metode yang dipakai adalah dengan descriptive content analysis study. metode descriptive content analysis study adalah analisis untuk mengambarkan isi dari suatu informasi atau teks tertentu (Munirah,2015). Analisis ini dilakukan pada berbagai artikel ilmiah yang terkait dengan perkuliahan daring di masa pandemi wabah Covid-19.

\section{PEMBAHASAN}

Kebijakan pemerintah untuk menjaga jarak guna meminimalisir penyebaran virus Covid-19 membuat aktivitas pembelajaran di sekolah dan perguruan tinggi dihentikan, sebagaimana yang terdapat dalam Surat Edaran Mendikbud Nomor 4 Tahun 2020 yang berisi tentang Pelaksanaan Kebijakan Pendidikan Dalam Masa Darurat Penyebaran Covid-19. Penghentian aktivitas pendidikan dilakukan untuk menghindari klaster baru penyebaran virus Corona di lingkungan sekolah ataupun di perguruan tinggi. Meski kegiatan di sekolah maupun perguruan tinggi diliburkan tidak berarti aktivitas belajar juga ikut dihentikan. Mendikbud mengatakan bahwa aktivitas belajar dilakukan dari rumah secara daring sehingga proses pembelajaran tetap berjalan seperti biasa meskipun tidak melakukan tatap muka secara langsung . (Kosasy,2020).

Selama adanya masa pandemi Covid-19 kuliah yang dilakukan dirumah atau secara daring menjadi solusi untuk melanjutkan sisa semester bagi mahasiswa. Pembelajaran secara daring merupakan pembelajaran yang dilakukan dengan menggunakan perangkat elektronik yang disambungkan ke jaringan internet. Pembelajaran secara daring bisa dijadikan sebuah strategi perkuliahan bagi para mahasiswa karena dapat dilakukan dengan menggunakan smartphone atau laptop (Suhartono,2020). Aplikasi yang bisa digunakan untuk melakukan perkuliahan daring dapat melalui aplikasi seperti Google Classroom, E-Learning, dan Whatsapp (Abidah et al., 2020). Diskusi bisa dilakukan layaknya bertemu tatap muka melalui beragam aplikasi yang banyak tersedia seperti Zoom dan Google Meet. Aplikasi tersebut menjadikan dosen dan mahasiswa dapat bertemu dan berinteraksi secara virtual dengan fasilitas pesan instans dan kegiatan presentasi (Wiranda \& Adri, 2019).

\section{Perkuliahan daring masih membingungkan mahasiswa

$$
\text { Menurut Kosssy }
$$ \\ Perkuliahan daring masih} membingungkan mahasiswa. Mahasiswa mengeluhkan banyaknya tugas yang diberikan tetapi tanpa adanya materi yang cukup dan penjelasan dari dosen sehingga sulit dalam mengikuti proses perkuliahan daring. Bahkan bagi mahasiswa pada aplikasi e-learning dan zoom ataupun gmeet juga masih membingungkan. Perkuliahan yang dilakukan secara daring membutuhkan adaptasi guna untuk lancarnya proses perkuliahan, selain itu juga dibutuhkan upaya agar dapat memahami materi perkuliahan yang biasanya disampaikan secara langsung tapi sekarang disampaikan menjadi dalam bentuk tulisan atau vidio. Adanya keluhan 
oleh para mahasiswa karena mereka merasakan bosan dengan metode perkuliahan yang monoton (Amany,2020).

\section{Monotonnya model perkuliahan}

Dalam melakukan perkuliahan secara daring yang perlu diperhatikan adalah model perkuliahan yang digunakan. Meskipun dengan berbagai aplikasi, tetapi dosen tetap harus mengetahui bagaimana model yang akan digunakan untuk perkuliahan karena perkuliahan yang dilakukan tanpa adanya rencana yang matang akan menyebabkan sulitnya bagi mahasiswa dan dosen dalam mencapai tujuan perkuliahan.

\section{Informasi yang kurang bermanfaat bagi mahasiswa}

Bersamaan dengan adanya informasi akademis yang dibagikan melalui media sosial berita mengenai Covid-19 juga ikut lalu lalang di media sosial dan hal tersebut dapat berpotensi menyebabkan timbulnya social media fatigue pada mahasiswa. Hal itu dapat menyebabkan seseorang tidak dapat berkonsentrasi terhadap apa yang dikerjakan (Rahardjo,2020). Hal ini tentu dapat memicu konsekuensi negatif lainnya yaitu menurunnya performa belajar.

\section{Mahasiswa mengalami stres}

Stres yang dialami oleh mahasiswa dipengaruhi oleh rasa takut tertular wabah Covid-19, kebosanan saat melakukan social distancing, dan sulitnya untuk memahami materi saat perkuliahan daring. Kesulitan muncul bukan hanya karena takut tertular Covid-19 tetapi juga terkait dengan banyaknya tugas yang diberikan dosen kepada mahasiswa dan menyebabkan beban berat mengingat ada beberapa mata kuliah yang harus dilaksanakan di masa pandemi Covid-19 ini. Sebelumnya mahahiswa sudah terbiasa dengan perkuliahan tatap muka sedangkan sekarang perkuliahan jarak jauh hanya dilakukan pada waktu tertentu saja tidak secara tetap. Perubahan pada pola perkuliahan ini menyebabkan munculnya tekanan dan mengakibatkan stres pada mahasiswa.

\section{PENUTUP}

Adanya wabah virus Covid-19 telah menyebabkan banyak perubahan terhadap semua aspek kehidupan manusia termasuk dalam hal pendidikan. Untuk meminimalisir penyebaran virus Covid-19 semua lembaga pendidikan diharuskan untuk menghentikan aktivitas pembelajaran secara tatap muka dan digantikan dengan metode daring. Perkuliahan yang dilakukan secara online ada dampak terhadap mahasiswa diantaranya yaitu perkuliahan yang dilaksanakan secara daring masih membingungkan mahasiswa, monotonnya model yang digunakan untuk perkuliahan, informasi yang kurang bermanfaat bagi mahasiswa, bisa mengakibatkan munculnya tekanan dan stres bagi manusia. Meskipun perkuliahan secara daring memiliki banyak dampak negatif tetapi perkuliahan secara daring juga memiliki beberapa manfaat yang positif yaitu antara lain dapat meningkatkan kadar interaksi antara dosen dengan mahasiswa, perkuliahan bisa dilakukan kapan saja dan dimana saja, serta mempermudah penyempurnaan penyimpanan materi perkuliahan.

\section{DAFTAR PUSTAKA}

Argaheni, Niken B. 2020. Sistematik Review : Dampak Perkuliahan Daring Saat Pandemi COVID19 Terhadap Mahasiswa Indonesia. PLACENTUM Jurnal Ilmiah Kesehatan dan Aplikasinya, 8(2), 99-108. https://doi.org/10.20961/place ntum.v8i2.43008

Firman, F., \& Rahayu,S. (2020). Pembelajaran Online di Tengah Pandemi Covid-19. Indonesian Journal of Educational Science (IJES), 2 (2),81-89.

https://doi.org/10.31605/ijes.v $\underline{2 \mathrm{i} 2.659}$ 
Jannah, S. N., Sobandi, A., \& Suwatno. (2020). The Measurement of Usability Using Use Questionnaire On The Google Classroom Application As ELearning Media (A Case Study: SMK Negeri 1 Bandung). Teknodika, 18 (2), 94-105.

https://doi.org/10.20961/tekno dika.v18i2.42486

Kosssy, SO. Model Pembelajaran Kobeko Berbasis Web Blog (Balada Pendidikan Tinggi di Tengah Kepungan Wabah COVID-19). JVEIT.2020; $1(1): 36-41$

Sadikin, Ali.2020. Pembelajaran Daring di Tengah Wabah Covid-19. BIODIK: Jurnal Ilmiah Pendidikan Biologi, 6 (2), hal.214-224.

Setiawan, Adib R. 2020. Lembar Kegiatan Literasi Saintifik untuk Pembelajaran Jarak Jauh Topik Penyakit Coronavirus 2019(COVID 19). EDUKATIF : Jurnal Ilmu Pendidikan, 2(1), hal. 28-37. http://dx.doi.org/10.31004/edu katif.v2i1.80

Widiyono, A. 2020. Efektifitas Perkuliahan Daring (Online) pada Mahasiswa PGSD di Saat Pandemi Covid 19. Jurnal Pendidikan,8 (2), 169-177. https://doi.org/10.36232/pendi dikan.v8i2.458 